\title{
1 An optimized strategy for cloning-based locus-specific bisulfite sequencing PCR
}

3 Mario Van Poucke ${ }^{1, *}$, Xanthippe Boulougouris ${ }^{1}$, Bart De Spiegeleer ${ }^{2}$, Christian Burvenich ${ }^{1}$, Luc

4 Duchateau $^{1}$ and Luc J. Peelman ${ }^{1}$

5

$6{ }^{1}$ Department of Nutrition, Genetics and Ethology, Faculty of Veterinary Medicine, Ghent

7 University, Heidestraat 19, B-9820 Merelbeke, Belgium

$8{ }^{2}$ Drug Quality and Registration (DruQuaR) group, Faculty of Pharmaceutical Sciences, Ghent

9 University, Ottergemsesteenweg 460, B-9000 Ghent, Belgium

$11{ }^{*}$ Correspondence: Dr Mario Van Poucke, Department of Nutrition, Genetics and Ethology, Faculty 12 of Veterinary Medicine, Ghent University, Heidestraat 19, B-9820 Merelbeke, Belgium; Tel +32 9

13 2647806; Fax +32 9 2647849; E-mail: Mario.VanPoucke@UGent.be

14

15 Keywords: bias, bisulfite conversion, clone, CpG island, epigenetic, method, methylation, UBC 16 integrity assay 
bioRxiv preprint doi: https://doi.org/10.1101/239566; this version posted December 25, 2017. The copyright holder for this preprint (which was not certified by peer review) is the author/funder, who has granted bioRxiv a license to display the preprint in perpetuity. It is made available under aCC-BY-NC 4.0 International license.

\section{ABSTRACT}

18 In this methods paper, we describe a successful strategy to investigate locus-specific methylation by

19 cloning-based bisulfite sequencing. We cover sample handling, DNA isolation, DNA quality control

20 before bisulfite conversion, bisulfite conversion, DNA quality control after bisulfite conversion, in

21 silico identification of CpG islands, methylation-independent bisulfite sequencing PCR (BSP) assay

22 design, methylation-independent BSP, cloning strategy, sequencing and data analysis. Methods that

23 are described nicely elsewhere will not be covered in detail. Instead, the focus will be on tips/tricks

24 and new methods/strategies used in this protocol, including quality control assessment of the DNA

25 before and after bisulfite conversion and a pooled cloning strategy to reduce time, costs and effort

26 during this step. In addition we comment on dealing with bias and improving overall protocol

27 efficiency. 
bioRxiv preprint doi: https://doi.org/10.1101/239566; this version posted December 25, 2017. The copyright holder for this preprint (which was not certified by peer review) is the author/funder, who has granted bioRxiv a license to display the preprint in perpetuity. It is made available under aCC-BY-NC 4.0 International license.

\section{INTRODUCTION}

29 There are a lot of ways to study DNA methylation. Depending on the scientific question, the

30 samples (type, quality, quantity, number), the laboratory equipment and funds, researchers can

31 compose their most appropriate strategy. Since all methods have their pros and cons, it is vital to

32 evaluate all steps for potential bias, take measures to prevent them and include necessary controls to

33 monitor them [1-2].

34 Here, we report our strategy for cloning-based locus-specific bisulfite sequencing PCR (BSP) to

35 investigate the methylation status of specific $\mathrm{CpG}$ islands at single base resolution. The strategy is

36 partially based on described strategies [3-11], but also contains some useful adaptations. This

37 strategy can be used to investigate if a gene specific expression change in an organism is caused by

38 an altered methylation status of that gene.

39 First, bisulfite treatment, the gold standard method in DNA methylation studies, will selectively

40 convert “unmethylated” cytosine (C) to uracil (U), while "methylated” C will not be converted [12].

41 It should be noted that other C-modifications, such as 5-formylcytosine (5-fC) and 5-

42 carboxylcytosine (5-caC), will be converted to $U$ as well, while others, such as 5-

43 hydroxymethylcytosine (5-hmC), will not be converted either. However, adapted methods exist to

44 study these rarer modifications separately [13-14].

45 Then, PCR is performed to selectively amplify the bisulfite-converted region of interest, whereby U

46 (native $\mathrm{C}$, 5-fC and 5-caC) will be replaced by thymine (T) and non-converted $\mathrm{C}$ (native 5-mC and

47 5-hmC) by C. After Sanger sequencing, all remaining Cs can be considered as "methylated” Cs in

48 the native sequence $(5-\mathrm{mC}$ or 5 -hmC). We prefer a cloning-based strategy (instead of direct

49 sequencing) in order to obtain DNA methylation haplotypes. In addition, the interpretation of the

50 peaks is unequivocally (no mixed bases, misaligned signals or PCR slippage). In order to make it 
bioRxiv preprint doi: https://doi.org/10.1101/239566; this version posted December 25, 2017. The copyright holder for this preprint (which was not certified by peer review) is the author/funder, who has granted bioRxiv a license to display the preprint in perpetuity. It is made available under aCC-BY-NC 4.0 International license.

51 less laborious, we maximize amplicon lengths based on the bisulfite-converted DNA quality control

52 and use a pooled cloning strategy.

\section{PROTOCOL}

\section{1) Sample handling}

56 Because bisulfite sequencing is most successful with intact starting material, tissue/DNA samples

57 should be handled/stored in a way that prevents DNA degradation. Well known key factors are

58 temperature (cold, avoiding freeze-thaw cycles), humidity (dry), sunlight (darkness) and time

59 (quick). For extensive guidelines see [15].

\section{2) DNA isolation}

61 Total DNA is isolated with the Quick-DNA Miniprep Plus Kit (including a Proteinase K digest,

62 according to the Zymo Research's recommendations), described to extract ultra-pure concentrated

63 RNA-free high-quality DNA from a wide range of biological sample types ready for bisulfite

64 sequencing (maximal binding capacity of the column is $25 \mu \mathrm{g}$ DNA and minimal elution volume is

$6535 \mu \mathrm{l}$ ). Many other kits or protocols are described that should work equally good [16]. At first use

66 we recommend to isolate DNA from a test sample and evaluate the procedure(s) based on the DNA

67 quality control results (see Protocol, section 3).

\section{3) DNA quality control before bisulfite conversion}

69 The quantity and purity of the extracted DNA is measured with Nanodrop as dsDNA (Isogen).

70 Integrity is evaluated by analysing $1 \mu \mathrm{g}$ of DNA on a $1 \%$ agarose gel and by performing the UBC

71 integrity assay on 5 ng DNA (Table 1 and Figure 1.A). The UBC integrity assay consists of a single

72 monoplex PCR reaction amplifying fragments of different lengths (137, 365, 593, 821,... bp)

73 analysed on a 2\% agarose gel [17]. Pure and intact DNA will allow amplification of all fragments,

74 while higher degrees of impurity and/or degradation will result in a decrease of amplification 
bioRxiv preprint doi: https://doi.org/10.1101/239566; this version posted December 25, 2017. The copyright holder for this preprint (which was not certified by peer review) is the author/funder, who has granted bioRxiv a license to display the preprint in perpetuity. It is made available under aCC-BY-NC 4.0 International license.

75 products starting with the longer amplicons. Implementation of the multi-use UBC integrity assay in

76 the lab is of particular interest since this single assay can not only be used for quality assessment of

77 DNA from different mammals (checking presence, integrity, amplificability), but also to estimate

78 the DNA contamination level in RNA samples and to perform quality assessment of cDNA reverse

79 transcribed from RNA isolated from any tissue (reflecting the RNA quality). Ideally, DNA should

80 be pure and integer (= OD260/280 around 1.8 on Nanodrop, a high molecular weight band on gel

81 and generation of all amplicons with the UBC integrity assay). Also for this step other methods (e.g.

82 fluorometric- or microfluidic-based methods) can be used to perform DNA quality control [18].

\section{4) Bisulfite conversion}

84 Bisulfite conversion is performed on 500 ng of RNA-free high-quality DNA with the EZ DNA

85 Methylation-Lightning Kit (according to the Zymo Research's recommendations), described to 86 convert $>99.5 \%$ of unmethylated Cs and to protect $>99.5 \%$ of methylated Cs, with a DNA

87 recovery of $>80 \%$. Higher input levels of DNA are not recommended because they might result in

88 incomplete bisulfite conversion. Recommended input levels can go as low as $100 \mathrm{pg}$, however this

89 will lower proportionally the number of downstream PCR reactions and the maximal fragment

90 length that can be amplified (because of the lower input of damaged DNA, the number of the longer

91 fragments might drop below the threshold for amplification). The bisulfite-converted DNA is eluted

92 in $10 \mu \mathrm{l}$ (around $40 \mathrm{ng} / \mu \mathrm{l}$ bisulfite-converted DNA). Many other kits or protocols are described that

93 can be used $[10,16]$. At first use we recommend to perform bisulfite conversion on a test sample and

94 evaluate the procedure(s) based on the DNA quality control results after bisulfite conversion (see

95 Protocol, section 5).

\section{5) DNA quality control after bisulfite conversion}

97 The quantity and purity of the DNA after bisulfite conversion, known to damage DNA, is measured 98 with Nanodrop as ssRNA (Isogen). Integrity and amplificability is evaluated by performing the 
bioRxiv preprint doi: https://doi.org/10.1101/239566; this version posted December 25, 2017. The copyright holder for this preprint (which was not certified by peer review) is the author/funder, who has granted bioRxiv a license to display the preprint in perpetuity. It is made available under aCC-BY-NC 4.0 International license.

99 UBC bisulfite integrity assay on 5 ng of bisulfite-converted DNA (Table 1 and Figure 1.B). It is a

100 similar assay as the one used for native DNA, but for DNA after bisulfite conversion [17].

101 Comparing the results of both integrity assays will give an idea about the impact of bisulfite

102 conversion on the DNA integrity of the sample. It will also give an idea about the maximal fragment

103 length that can be PCR amplified from the sample. Because of the fragility of bisulfite-converted

104 DNA, it is advised to proceed immediately to PCR and freeze the rest in aliquots.

105 6) In silico identification of CpG islands

106 In silico identification of CpG islands in target genes is based on common hits in different genome

107 browsers (Ensembl, UCSC and NCBI) and online tools such as CpG Islands (The Sequence

108 Manipulation Suite), DBCAT, Cpgplot (EMBOSS) and MethPrimer [19-25].

109 7) Methylation-independent BSP assay design

110 Methylation-independent BSP primer design and electronic PCR, detecting potential mispriming 111 sites and undesired PCR products, is performed by BiSearch [26]. To our knowledge, it is the only 112 free software combining BSP primer design and electronic PCR. Customized parameters are 113 discussed below.

114 Because bisulfite-converted DNA is not complementary anymore, a choice has to be made whether

115 to design primers amplifying the sense or the antisense strand. We suggest to try both strands and 116 choose the most optimal primers. Because of the symmetry of the CpG motifs and the mode of 117 action of the methyltransferases, the methylation status of every CpG motif should be identical to its 118 complement, unless the region of interest is prone to hemimethylation [27]. Signs for 119 hemimethylation can be observed by analysing the methylation status of CpGs in overlapping parts 120 of amplicons targeting the different strands and warrant further investigation.

121 Amplicon length is based on the length of the CpG island to be analysed (see Protocol, section 6), 122 the integrity and amplificability of the bisulfite-converted DNA (see Protocol, section 5) and the 
bioRxiv preprint doi: https://doi.org/10.1101/239566; this version posted December 25, 2017. The copyright holder for this preprint (which was not certified by peer review) is the author/funder, who has granted bioRxiv a license to display the preprint in perpetuity. It is made available under aCC-BY-NC 4.0 International license.

123 cloning strategy (see Protocol, section 9). Using the described protocol, amplicons up to 800 bp can

124 be amplified starting from high-quality DNA.

125 Because of the bisulfite conversion, 4-base DNA (25\% of A, G, C and T) will be shifted towards 3126 base DNA (towards 25\% A, 25\% G, 0\% C and $50 \%$ T), reducing DNA complexity. In order to have 127 the same specificity, bisulfite primers might need to be longer compared to native primers.

128 In case an estimate of the primer occurrence in a particular template is wanted, the following 129 formula can be used: $\mathrm{N} \times\left(\mathrm{pA}^{\wedge} \mathrm{Na}\right) \times\left(\mathrm{pG}^{\wedge} \mathrm{Ng}\right) \times\left(\mathrm{pC}^{\wedge} \mathrm{Nc}\right) \times\left(\mathrm{pT}^{\wedge} \mathrm{Nt}\right)$, with $\mathrm{N}$ being the number of 130 nucleotides in the template, $\mathrm{pA} / \mathrm{pG} / \mathrm{pC} / \mathrm{pT}$ the estimated frequencies of the respective nucleotides in 131 that template (sum should be 1 ) and $\mathrm{Na} / \mathrm{Ng} / \mathrm{Nc} / \mathrm{Nt}$ the number of the respective nucleotides in the 132 primer. In an average mammalian genome of 3x10^9 bp (assuming that every nucleotide appears at 133 25\%), a native primer of 20 bp (containing 5 times each nucleotide) would theoretically occur 1340,0027 times $\left(=\left(3 \times 10^{\wedge} 9\right) \times(0.25 \wedge 5) \times\left(0.25^{\wedge} 5\right) \times(0.25 \wedge 5) \times(0.25 \wedge 5)\right)$, so considered to be highly 135 specific. For bisulfite primers in a hypothetical $100 \%$ methylated genome ( $0 \% \mathrm{C}$ converted to $\mathrm{T})$, it 136 would be the same. In a hypothetical $100 \%$ unmethylated genome (100\% C converted to T) a 137 similar 20-bp primer (all 5 Cs converted to Ts) would occur 3 times $\left(=\left(3 \times 10^{\wedge} 9\right) \times(0.25 \wedge 5) \times\right.$ $\left.138\left(0.25^{\wedge} 5\right) \times\left(0^{\wedge} 0\right) \times\left(0.5^{\wedge} 10\right)\right)$, so considered to be not specific. In a genome where $40 \%$ of the Cs 139 would be methylated, a similar 20-bp primer (3 out of 5 Cs would be converted to T) would occur 1400.02 times $\left(=\left(3 \times 10^{\wedge} 9\right) \times\left(0.2^{\wedge} 5\right) \times\left(0.25^{\wedge} 5\right) \times\left(0.1^{\wedge} 2\right) \times(0.4 \wedge 8)\right)$, about 10 times less specific than 141 the respective native primer.

142 Taking into account the completeness of genome databases, the specificity of potential PCR primers 143 can be checked via the fast PCR tool of BiSearch using the 16-mer mismatch string parameter to 144 specify nucleotide specific differences (e.g. random mismatch in the genome and Cs that might or 145 might not be converted after bisulfite treatment). In addition, the native versions of the bisulfite 146 primers can be checked for known SNPs via NCBI-BLAST in order to prevent null-alleles [28]. 
147 To avoid that primer annealing is affected by the methylation status of the primer target sequence,

148 primers should not contain CpGs. In case they do, degenerate primers should be designed with a Y

149 (C or T) instead of a C. Amplifying unconverted DNA can be prevented by including some non-

150 CpG Cs in the native primer sequence (they will be replaced by Ts in the bisulfite primer and as a

151 result only be specific for converted DNA). To make sure, it can be experimentally verified that

152 methylation-independent primers do not amplify unconverted DNA.

153 Annealing temperatures should be as high as possible to prevent potential secondary structures in 154 the template and avoiding primer dimer formation. Inter-primer melting temperature (Tm) 155 differences should be as low as possible (lower than $1^{\circ} \mathrm{C}$ ) to prevent non-binding of the primer with 156 the lower Tm or non-specific binding of the primer with the higher Tm.

\section{8) Methylation-independent BSP}

158 Because PCR on bisulfite-converted DNA is prone to non-specific amplification due to its high AT 159 content, it is strongly recommended to use a HotStart polymerase. From the wide range of available DNA polymerases, we use TEMPase HotStart Polymerase (according to VWR's recommendations), designed to diminish the formation of non-specific priming events during reaction set-up and the

162 first ramp of thermal cycling. It is a non-proofreading DNA polymerase (produces 3'-A overhangs), 163 allowing TA cloning (see Protocol, section 9). Other DNA polymerases can be used, but not all. 164 Archaeal polymerases, such as the high-fidelity polymerases Vent and Pfu, are unable to efficiently copy bisulfite-converted DNA due to the stalling triggered by template uracil [29]. In addition, unmodified high-fidelity polymerases will complicate subsequent TA-cloning, because they do not

167 produce 3'-A overhangs.

168 PCR is performed for 40 cycles $\left(30^{\prime \prime}-95^{\circ} \mathrm{C}, 30^{\prime \prime}-\mathrm{Ta}, 2^{\prime}-72^{\circ} \mathrm{C}\right)$ with $5 \mathrm{ng}$ bisulfite-converted DNA as 169 a template (= on average 80 reactions can be performed per conversion) on a S1000 Thermal Cycler 170 (Bio-Rad) with gradient function. During optimization of the assays, a 5-point gradient PCR is 
171 performed with as annealing temperature (Ta) the predicted $\mathrm{Tm}-4^{\circ} \mathrm{C},-2^{\circ} \mathrm{C},+0^{\circ} \mathrm{C},+2^{\circ} \mathrm{C}$ and $+4^{\circ} \mathrm{C}$.

172 Amplicons are analysed on a 2\% agarose gel. The averaged Ta of all Ta with specific amplification

173 is chosen as assay Ta. Because of the complexity of the PCR reaction (fragmented DNA, low

174 complexity target, presence of $U$ ) it might be needed to increase extension times.

\section{9) Cloning strategy}

176 If multiple fragments need to be analysed, we opt for a pooled cloning strategy in pCRII (TA-

177 cloning kit, Invitrogen) in order to reduce time, costs and effort during this step. Ideally, pooled

178 amplicons should differ in length (the longer the amplicons, the longer the difference). After PCR

179 on bisulfite-converted DNA with a non-proofreading DNA polymerase, the different amplicons are

180 analysed on a 2\% agarose gel, cut out with a scalpel and eluted together (up to 4 different

181 amplicons) with the GENECLEAN II kit (MP Biomedicals) in $8 \mu$ l. One $\mu$ l of the eluted amplicon

182 mix is analysed on a $2 \%$ agarose gel to validate the amplicon quantities (Figure 1.C). Six $\mu l$ of the

183 eluted amplicon mix is then ligated in $1 \mu$ pCRII with $1 \mu$ T4 DNA ligase (= 1 U) and $2 \mu l$ xx T4

184 DNA ligase buffer at $14^{\circ} \mathrm{C}$ overnight. Two $\mu$ l of the ligation mix is then transformed into $50 \mu \mathrm{l}$

185 Subcloning Efficiency DH5 $\alpha$ Competent Cells and grown overnight on LB plates containing 100

$186 \mu \mathrm{g} / \mathrm{ml}$ ampicillin and $50 \mu \mathrm{g} / \mathrm{ml} \mathrm{X-gal} \mathrm{(allowing} \mathrm{blue/white} \mathrm{screening;} \mathrm{according} \mathrm{to} \mathrm{Invitrogen’s}$

187 instructions). The next day, individual white colonies (containing 1 insert) are striped on new plates

188 and grown overnight. The next day, a tip-point of cells is resuspended in $100 \mu \mathrm{l}$ water and $2 \mu \mathrm{l}$ is

189 used for colony PCR. If the amplicon length difference of the pooled fragments can be

190 distinguished on a 2\% agarose gel, pCRII primers bordering the TA cloning site can be used to

191 amplify the insert to be sequenced (Table 1). Two $\mu$ l of the PCR product can be analysed on a $2 \%$

192 agarose gel to check the amount and the identity of the insert based on fragment length (Figure

193 1.D). By doing so, the amount of input for sequencing and the number of clones to be sequenced

194 from each pooled fragment can be controlled. If some of the pooled fragments can not be 
bioRxiv preprint doi: https://doi.org/10.1101/239566; this version posted December 25, 2017. The copyright holder for this preprint (which was not certified by peer review) is the author/funder, who has granted bioRxiv a license to display the preprint in perpetuity. It is made available under aCC-BY-NC 4.0 International license.

195 distinguished from each other by length, they can be first cut with a specific restriction enzyme

196 before gel analysis, or fragment specific primers can be used on the undetermined clones. If

197 preferring another cloning strategy, the above-mentioned issues can be adopted as needed.

\section{0) Sequencing}

199 The rest of the colony PCR product (= $8 \mu \mathrm{l}$ ) of the selected clones (at least 6 for every fragment) is

200 cleaned-up for Sanger sequencing by adding 4 U exonuclease I (Bioké) and 2 U antarctic 201 phosphatase (Bioké), and incubating for $30 \mathrm{~min}$ at $37^{\circ} \mathrm{C}$ (enzymatic reaction) and 15 min at $80^{\circ} \mathrm{C}$ 202 (enzyme inactivation). Two $\mu \mathrm{l}$ of the treated PCR product is usually (depending on its amount based 203 on Figure 1.D) used for the sequencing reaction with the BigDye Terminator v3.1 Cycle Sequencing 204 Kit (Applied Biosystems; Table 2) using one or both (depending on the length of the insert) PCR 205 primers as individual sequencing primer.

\section{11) Data analysis}

207 The chromatograms are inspected manually for errors and the sequences are trimmed (insert 208 without amplicon specific primer sequences, because they do not represent the methylation status of 209 the native fragment) with BioEdit (free software) [30]. Extracting the methylation data (including 210 quality control and visualisation in lollipop-style) is performed with BiQ Analyzer (free software) $211[31]$.

\section{COMMENTARY}

\section{1) Dealing with bias}

215 It is important to evaluate every step of the protocol for a potential introduction of bias. Most 216 critical is probably the conversion efficiency of the bisulfite treatment. According to the 217 specifications of the kit used in our protocol the conversion efficiency is $>99.5 \%$ (= less than 1 218 error per $200 \mathrm{CpGs).} \mathrm{For} \mathrm{a} \mathrm{hypothetical} \mathrm{amplicon} \mathrm{of} 400$ bp containing $40 \mathrm{CpGs}$, this would mean 
219 less than $1 \mathrm{CpG}$ error per 5 amplicons. Experimental bisulfite conversion efficiencies can be

220 estimated by calculating the percentage of non-CpG Cs in the native amplicon sequence that are

221 really converted to Ts in the bisulfite-converted sequence (one of the QC parameters of BiQ

222 Analyzer). Including non-CpG Cs in the native primer sequence will prevent amplification of

223 unconverted DNA and thus lower potential bias.

224 Another source of potential bias is caused by PCR. According to the PCR Fidelity Calculator 225 (ThermoFischer Scientific) [32], amplification of the hypothetical 400-bp fragment for 40 cycles 226 with Taq DNA polymerase would introduce 1 error in $1 / 3$ of the amplicons. Because only C>T 227 errors at methylated CpGs or T $>$ C errors at unmethylated CpGs (= 1/3 of all possible errors) of the 22840 CpGs of the amplicon (= 1/10 of the sequence) would create bias (all other errors would be 229 noticed as errors), this would theoretically result in a wrong determination of the methylation status 230 of only $1 \mathrm{CpG}$ per 90 amplicons (= 1/3 *1/3*1/10; almost 20-fold less than bisulfite conversion 231 errors). Because we perform cloning-based sequencing involving colony PCR with a non-high232 fidelity DNA polymerase, a similar PCR bias is created during this step. However, there would be 233 no implications here when using a high-fidelity DNA polymerase to lower this bias. In addition, it 234 might even lower potential PCR slippage (another PCR bias), typically due to sequential Ts (N>9). 235 In case PCR slippage during colony PCR hinders sequencing (not an issue before cloning), 236 sequencing could be performed on DNA extracted from a single clone (instead of performing 237 colony PCR).

238 To test if the primers amplify methylation independent (and not in favour of unmethylated 239 templates), PCR on a 50:50 methylated/unmethylated bisulfite converted control sample is 240 frequently performed. To make sure that all tested amplicons are really 50:50 241 methylated/unmethylated, all regions under investigation are first PCR amplified with native 242 primers on native DNA as a template (these amplicons can contain multiple overlapping BSP 


\section{3}

244

245

246

247

248

249

250

251

252

253

amplicons). These $100 \%$ unmethylated amplicons are mixed and split into two parts. One part will serve as the unmethylated part, the second part will be $100 \% \mathrm{CpG}$ methylated by a CpG methyltransferase treatment (M.SssI, Bioké). This can be verified by cutting an aliquot of both parts with HpaII (Bioké). It will cut unmethylated CCGG (= unmethylated part 1), but not methylated CCGG (= methylated part 2). Both parts are then mixed, cleaned-up (QIAquick DNA purification kit, Qiagen) and bisulfite converted. Then all BSP assays are performed and amplicons digested with HpaII and TaqI. HpaII (cuts CCGG) will not cut bisulfite converted DNA (unmethylated CCGG will be converted to TTGG and methylated CCGG will be converted to TCGG). So, if none of the amplicons are digested it means that the bisulfite conversion was successful. TaqI (cuts TCGA) will not cut the unmethylated part (all native TCGA sequences are converted to TTGA), but will cut the methylated part (all native TCGA will not be converted and all CCGA will be converted to TCGA). So, if half of the amplicons are digested it means that the assays amplify methylation independent.

In order to have a reliable estimate of the methylation status and to minimize the effect of a potential error at every single $\mathrm{CpG}$, six clones are sequenced. To obtain a more precise determination of the methylation status of partially methylated loci, additional clones containing those loci can be sequenced or methylation specific primers targeting those loci can be used as deemed fit. In case of doubt about cloning bias, direct sequencing can be performed and the results compared with the ones obtained via cloning-based sequencing.

Results from identical sequences from overlapping amplicons can also be used to evaluate the reliability of the results. In addition, chromatograms are inspected manually in order to avoid base calling errors during sequencing.

Finally, it is obvious that positive and negative controls should be performed and contamination should be avoided at any time. 
bioRxiv preprint doi: https://doi.org/10.1101/239566; this version posted December 25, 2017. The copyright holder for this preprint (which was not certified by peer review) is the author/funder, who has granted bioRxiv a license to display the preprint in perpetuity. It is made available under aCC-BY-NC 4.0 International license.

\section{2) Improving overall protocol efficiency}

268 It is important to avoid DNA degradation because bisulfite sequencing is most successful with intact

269 starting material. In addition, it will allow you to amplify longer amplicons (determined by the UBC

270 bisulfite integrity assay), resulting in less amplicons to process. In order to maximize the chance to

271 reach the threshold number of fragments for amplification of these longer fragments, the maximal

272 advised DNA input for bisulfite conversion is used.

273 The protocol involves 2 PCR steps, one PCR on bisulfite-converted DNA before cloning and one

274 colony PCR. Because the theoretical bias created by the DNA polymerase is about 20-fold lower

275 than the bias created during bisulfite conversion, there is no big benefit to use more expensive high-

276 fidelity DNA polymerases, that even might complicate TA cloning. In our opinion, if primer design

277 guidelines are followed properly, there is no need for optimization (except for determining the

278 optimal experimental Ta) or performing (semi)-nested PCR.

279 Because cloning-based bisulfite sequencing is labour intensive, the pooled cloning strategy really

280 makes it more efficient. If pooled amplicons differ at least $50 \mathrm{bp}$ in length, their clones can easily be

281 distinguished from each other by a single colony PCR with universal vector primers. If not,

282 additional work might be needed to identify the clones in order not to sequence too many clones

283 containing the same amplicon. Although we were able to amplify amplicons of $800 \mathrm{bp}$, it is always

284 easier to amplify, clone and sequence smaller amplicons. In the pooled cloning strategy we used no

285 more than 4 amplicons between 350 and 500 bp.

286 At last, using free data analysis software, such as BiQ Analyser, minimizes errors and speeds up the 287 analysis. 
bioRxiv preprint doi: https://doi.org/10.1101/239566; this version posted December 25, 2017. The copyright holder for this preprint (which was not certified by peer review) is the author/funder, who has granted bioRxiv a license to display the preprint in perpetuity. It is made available under aCC-BY-NC 4.0 International license.

\section{ACKNOWLEDGEMENTS}

289 We wish to thank Carolien Rogiers, Dominique Vander Donckt, Linda Impe and Ruben Van 290 Gansbeke for excellent technical assistance.

\section{CONFLICT OF INTEREST}

293 The authors declare no conflict of interest

\section{REFERENCES}

296 [1] Kurdyukov S, Bullock M: DNA Methylation Analysis: Choosing the Right Method. Biology 297 2016; 5:3. doi: 10.3390/biology5010003.

298 [2] Olkhov-Mitsel E, Bapat B: Strategies for discovery and validation of methylated and 299 hydroxymethylated DNA biomarkers. Cancer Med 2012; 1:237-60. doi: 10.1002/cam4.22.

300 [3] Clark SJ, Harrison J, Paul CL, Frommer M: High sensitivity mapping of methylated cytosines. 301 Nucleic Acids Res 1994; 22:2990-7.

302 [4] Warnecke PM, Stirzaker C, Song J, Grunau C, Melki JR, Clark SJ: Identification and resolution 303 of artifacts in bisulfite sequencing. Methods 2002; 27:101-7.

304 [5] Wojdacz TK, Hansen LL, Dobrovic A: A new approach to primer design for the control of PCR 305 bias in methylation studies. BMC Res Notes 2008; 1:54. doi: 10.1186/1756-0500-1-54.

306 [6] Zhang Y, Rohde C, Tierling S, et al: DNA methylation analysis by bisulfite conversion, cloning, 307 and sequencing of individual clones. Methods Mol Biol 2009; 507:177-87. doi: 10.1007/978-1308 59745-522-0_14.

309 [7] Darst RP, Pardo CE, Ai L, Brown KD, Kladde MP: Bisulfite sequencing of DNA. Curr Protoc 310 Mol Biol 2010; Chapter 7:Unit 7.9.1-17. doi: 10.1002/0471142727.mb0709s91. 
bioRxiv preprint doi: https://doi.org/10.1101/239566; this version posted December 25, 2017. The copyright holder for this preprint (which was not certified by peer review) is the author/funder, who has granted bioRxiv a license to display the preprint in perpetuity. It is made available under aCC-BY-NC 4.0 International license.

311 [8] Li Y, Tollefsbol TO: DNA methylation detection: bisulfite genomic sequencing analysis.

312 Methods Mol Biol 2011; 791:11-21. doi: 10.1007/978-1-61779-316-5_2.

313 [9] Patterson K, Molloy L, Qu W, Clark S: DNA methylation: bisulphite modification and analysis.

$314 J$ Vis Exp 2011; 56:e3170. doi: 10.3791/3170.

315 [10] Hernández HG, Tse MY, Pang SC, Arboleda H, Forero DA: Optimizing methodologies for 316 PCR-based DNA methylation analysis. Biotechniques 2013; 55:181-97. doi: 10.2144/000114087.

317 [11] Methylation Analysis by Bisulfite Sequencing: Chemistry, Products and Protocols from

318 Applied Biosystems. URL: https://tools.thermofisher.com/content/sfs/manuals/cms_039258.pdf. 319 [accessed 05-12-2017].

320 [12] Frommer M, McDonald LE, Millar DS, et al: A genomic sequencing protocol that yields a 321 positive display of 5-methylcytosine residues in individual DNA strands. Proc Natl Acad Sci U S A 322 1992; 89:1827-31.

323 [13] Neri F, Incarnato D, Krepelova A, Parlato C, Oliviero S: Methylation-assisted bisulfite 324 sequencing to simultaneously map $5 \mathrm{fC}$ and $5 \mathrm{caC}$ on a genome-wide scale for DNA demethylation 325 analysis. Nat Protoc 2016; 11:1191-205. doi: 10.1038/nprot.2016.063.

326 [14] Booth MJ, Branco MR, Ficz G, et al: Quantitative sequencing of 5-methylcytosine and 5327 hydroxymethylcytosine at single-base resolution. Science 2012; 336:934-7. doi: 328 10.1126/science.1220671.

329 [15] Doorenweerd C, Beentjes K: Extensive guidelines for preserving specimen or tissue for later 330 DNA work. URL: https://science.naturalis.nl/media/medialibrary/2013/08/preservingdna.pdf 331 [accessed 17-08-2017].

332 [16] Holmes EE, Jung M, Meller S, et al: Performance evaluation of kits for bisulfite-conversion of 333 DNA from tissues, cell lines, FFPE tissues, aspirates, lavages, effusions, plasma, serum, and urine. 334 PLoS One 2014; 9:e93933. doi: 10.1371/journal.pone.0093933. 
335 [17] Van Poucke M, Peelman L: Flexible, multi-use, PCR-based nucleic acid integrity assays based 336 on the ubiquitin C gene. bioRxiv 2017; doi.org/10.1101/168195.

337 [18] Zonta E, Nizard P, Taly V: Assessment of DNA Integrity, Applications for Cancer Research.

338 Adv Clin Chem 2015; 70:197-246. doi: 10.1016/bs.acc.2015.03.002.

339 [19] Yates A, Akanni W, Ridwan Amode M, et al: Ensembl 2016. Nucleic Acids Res 2016; 340 44:D710-6. doi:10.1093/nar/gkv1157.

341 [20] Kent WJ, Sugnet CW, Furey TS, et al: The human genome browser at UCSC. Genome Res 342 2002; 12:996-1006.

343 [21] National Center for Biotechnology Information (NCBI)[Internet]. Bethesda (MD): National 344 Library of Medicine (US), National Center for Biotechnology Information; [1988] - [cited 2017 345 Aug 17]. Available from: https://www.ncbi.nlm.nih.gov/.

346 [22] Stothard P: The Sequence Manipulation Suite: JavaScript programs for analyzing and 347 formatting protein and DNA sequences. Biotechniques 2000; 28:1102-4.

348 [23] Kuo HC, Lin PY, Chung TC, et al: DBCAT: database of CpG islands and analytical tools for 349 identifying comprehensive methylation profiles in cancer cells. J Comput Biol. 2011; 18:1013-7. 350 doi: $10.1089 / \mathrm{cmb} .2010 .0038$.

351 [24] Larsen F, Gundersen G, Lopez R, Prydz H: CpG islands as gene markers in the human 352 genome. Genomics. 1992; 13:1095-107.

353 [25] Li LC, Dahiya R: MethPrimer: designing primers for methylation PCRs. Bioinformatics. 2002; 354 18:1427-31.

355 [26] Tusnády GE, Simon I, Váradi A, Arányi T: BiSearch: Primer-design and Search Tool for PCR 356 on Bisulfite Treated Genomes. Nucleic Acids Res 2005; 33:e9.

357 [27] Sun S, Li P: HMPL: a Pipeline for Identifying Hemimethylation Patterns by Comparing two 358 samples. Cancer Informatics 2015; 14:235-45. doi: 10.4137/CIN.S17286. 
359 [28] Blast [Internet]. Bethesda (MD): National Library of Medicine (US), National Center for

360 Biotechnology Information; 2004 - $[$ cited 2017 Feb 11]. Available from:

361 https://blast.ncbi.nlm.nih.gov/Blast.cgi.

362 [29] Lasken RS, Schuster DM, Rashtchian A: Archaebacterial DNA polymerases tightly bind uracil363 containing DNA. J Biol Chem 1996; 271:17692-6.

364 [30] Hall TA: BioEdit: a user-friendly biological sequence alignment editor and analysis program 365 for Windows 95/98/NT. Nucl. Acids. Symp. Ser 1999; 41:95-8.

366 [31] Bock C, Reither S, Mikeska T, Paulsen M, Walter J, Lengauer T: BiQ Analyzer: visualization 367 and quality control for DNA methylation data from bisulfite sequencing. Bioinformatics 2005; 21: 368 4067-8.

369 [32] PCR fidelity calculator (ThermoFisher Scientific). Available from: 370 https://www.thermofisher.com/us/en/home/brands/thermo-scientific/molecular-biology/molecular-

371 biology-learning-center/molecular-biology-resource-library/thermo-scientific-web-tools/pcr-

372 fidelity-calculator.html. Accessed 21 November, 2017.

373 [33] Boulougouris et al: personal communication (2017). 
bioRxiv preprint doi: https://doi.org/10.1101/239566; this version posted December 25, 2017. The copyright holder for this preprint (which was not certified by peer review) is the author/funder, who has granted bioRxiv a license to display the preprint in perpetuity. It is made available under aCC-BY-NC 4.0 International license.

\section{FIGURES}

375 Figure 1. Agarose gels showing A) UBC integrity assay on genomic DNA before bisulfite conversion (Protocol, section 3; adapted from [17]), B) UBC bisulfite integrity assay on genomic DNA from (A) after bisulfite conversion (Protocol, section 5; adapted from [17]), C) eluted 4-amplicon mix amplified on genomic DNA from (B) before cloning (Protocol, section 9; adapted from [33]), and D) colony PCR with pCRII primers on 5 clones containing amplicons from (C) (Protocol, section 9; adapted from [33]). M: 1 kb+ ladder (ThermoFisher

A

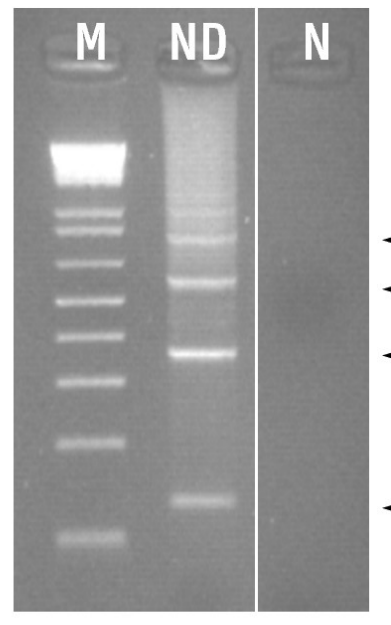

c

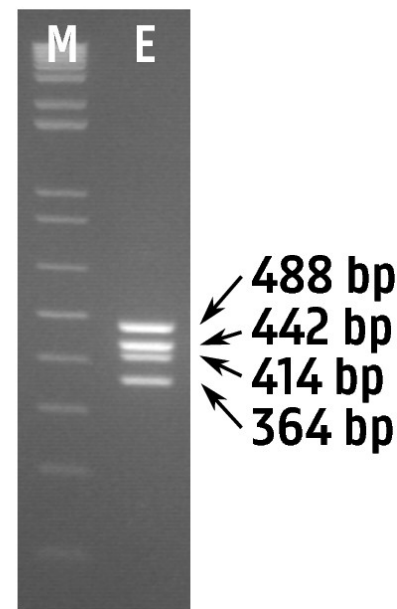

821 bp

593 bp

365 bp

$\leftarrow 137$ bp
B

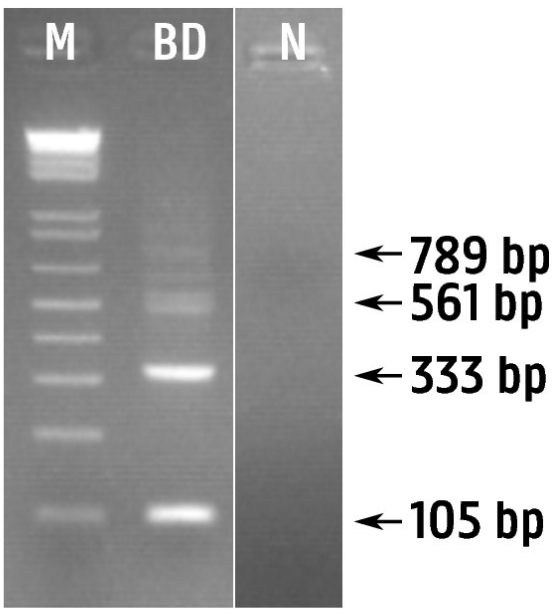

D $\mathrm{M} \mathrm{C1} C 2 \mathrm{C3} C 4 \quad \mathrm{C5}$ N

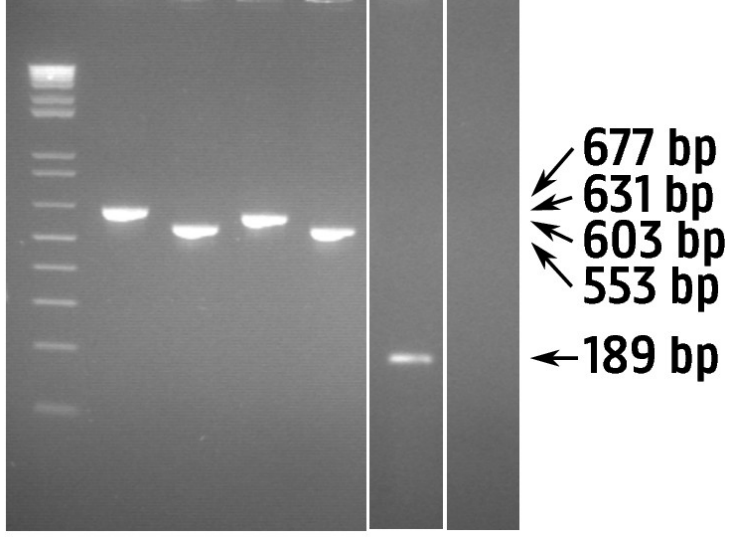




\section{TABLES}

385 Table 1. PCR details of the UBC (bisulfite) integrity [17] and pCRII assays.

\begin{tabular}{|r|l||c|c|l|}
\hline \multicolumn{2}{|l||}{ PCR mix (VWR) } & \multicolumn{3}{l|}{ Cycling program } \\
\hline $5.7 \mu \mathrm{l}$ & $\mathrm{H}_{2} \mathrm{O}$ & $14^{\prime} 30^{\prime \prime}$ & $95^{\circ} \mathrm{C}$ & \\
\hline $1.0 \mu \mathrm{l}$ & $10 \mathrm{x}$ Key Buffer & $00^{\prime} 30^{\prime \prime}$ & $95^{\circ} \mathrm{C}$ & ] \\
\hline $1.0 \mu \mathrm{l}$ & $10 \mu \mathrm{M}$ primers $\left(5 \mu \mathrm{M}\right.$ each primer $\left.^{123}\right)$ & $00^{\prime} 30^{\prime \prime}$ & $\mathrm{Ta}^{\circ} \mathrm{C}^{123}$ & ] $\mathrm{x} 40$ \\
\hline $0.2 \mu \mathrm{l}$ & $40 \mathrm{mM}$ dNTPs $(10 \mathrm{mM}$ each nucleotide) & $02^{\prime} 00^{\prime \prime}$ & $72^{\circ} \mathrm{C}$ & ] \\
\hline $0.1 \mu \mathrm{l}$ & $5 \mathrm{U} / \mu \mathrm{l}$ TEMPase Hot Start DNA Polymerase & $05^{\prime} 00^{\prime \prime}$ & $72^{\circ} \mathrm{C}$ & \\
\hline $2.0 \mu \mathrm{l}$ & Template & Hold & $15^{\circ} \mathrm{C}$ & \\
\hline $10.0 \mu \mathrm{l}$ & Total volume & & & \\
\hline
\end{tabular}

$387 \quad 1 \quad$ UBC integrity assay: amplicons of $137,365,593,821, \ldots$ bp $\left(\mathrm{Ta}=68^{\circ} \mathrm{C}\right)$

388 F: 5'-GCACCCTGTCHGACTACAACATCCAGAA-3’

\section{R: 5’-ATGGTGTCRCTGGGCTCSACYTC-3’}

UBC bisulfite integrity assay: amplicons of $105,333,561,789, \ldots$ bp $\left(\mathrm{Ta}=54^{\circ} \mathrm{C}\right)$ 
bioRxiv preprint doi: https://doi.org/10.1101/239566; this version posted December 25, 2017. The copyright holder for this preprint (which

was not certified by peer review) is the author/funder, who has granted bioRxiv a license to display the preprint in perpetuity. It is made available under aCC-BY-NC 4.0 International license.

396 Table 2. Sanger sequencing details (BigDye Terminator v3.1 Cycle Sequencing Kit, Applied Biosystems)

\begin{tabular}{|r|l||c|c|l|}
\hline \multicolumn{2}{|l||}{ Sequencing mix } & \multicolumn{3}{l|}{ Cycling program } \\
\hline $3.0 \mu \mathrm{l}$ & $\mathrm{H}_{2} \mathrm{O}$ & $2^{\prime} 00^{\prime}$ & $95^{\circ} \mathrm{C}$ & \\
\hline $0.5 \mu \mathrm{l}$ & Ready Reaction mix & $0^{\prime} 20^{\prime}$ & $95^{\circ} \mathrm{C}$ & ] \\
\hline $2.0 \mu \mathrm{l}$ & $5 \mathrm{x}$ sequencing buffer ${ }^{1}$ & $0^{\prime} 10^{\prime}$ & $60^{\circ} \mathrm{C}$ & ] $\mathrm{x} 30$ \\
\hline $1.0 \mu \mathrm{l}$ & GC-rich solution (Roche) & $4^{\prime} 00^{\prime}$ & $65^{\circ} \mathrm{C}$ & ] \\
\hline $1.5 \mu \mathrm{l}$ & Sequencing primer $(2 \mu \mathrm{M})$ & & & \\
\hline $2.0 \mu \mathrm{l}$ & Template & & \\
\hline $10.0 \mu \mathrm{l}$ & Total volume & & & \\
\hline
\end{tabular}

${ }^{1} 200$ mM Tris-HCl, pH $8+5$ mM MgCl 2 